\section{New PCD school opens}

A new School of Professionals Complementary to Dentistry was opened last month at The University of Portsmouth, by Health Minister Rosie Winterton.

Named after William Beatty, Lord Nelson's surgeon and dentist on-board the HMS Victory at the Battle of Trafalgar, the new School is housed in a $£ 4 m$ purpose built building and includes a 24-bay treatment clinic, two private surgeries, a phantom head skills laboratory and a dental radiography suite.

The School is the first of its kind in the country and offers a range of courses in response to the national shortage of dental professionals. The training model is one of

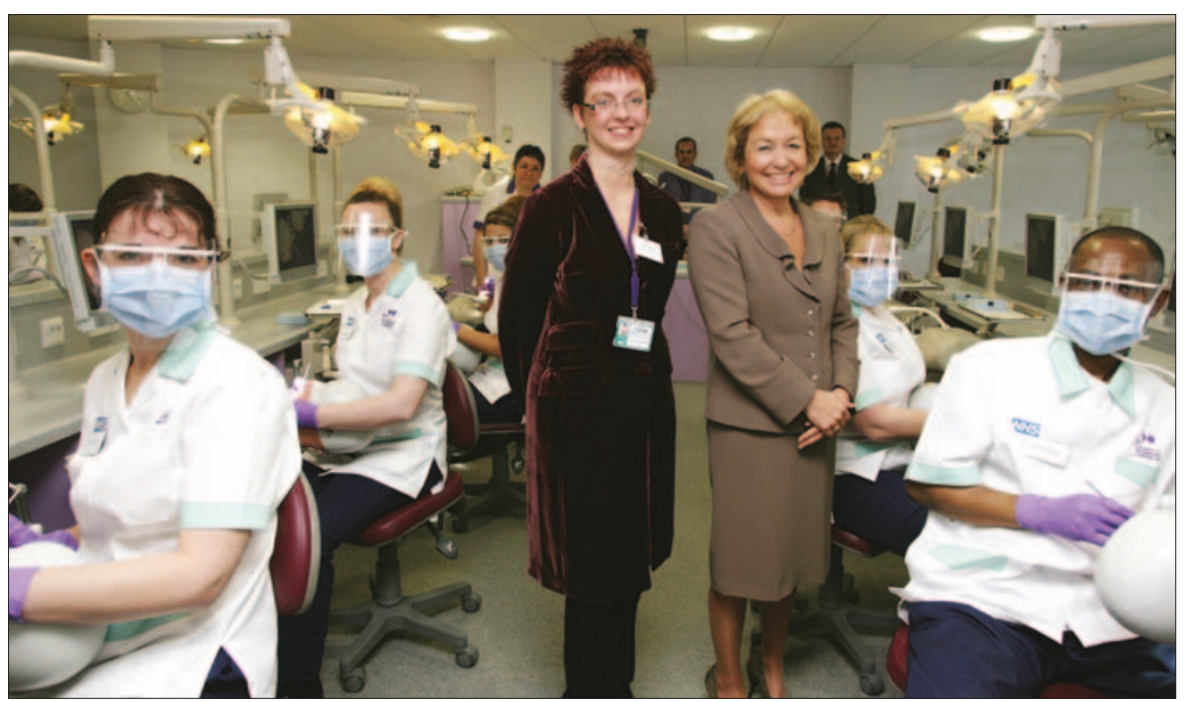

Sara Holmes, Head of the School of Professionals Complementary to Dentistry (left) with Health Minister Rosie Winterton and students at the School

\section{New qualification}

The National Examining Board for Dental Nurses has recently introduced a new qualification for dental nurses interested in or involved with radiography.

The Dental Radiography for Dental Nurses National Examination and Certificate is a qualification consisting of a national curriculum which is based on the British Society of Dental Maxillofacial Radiology's national curriculum for dental students.

This recommends approximately 40 hours of instruction consisting of 20 hours of practical experience and 20 hours of theoretical teaching. Practical training can be undertak- team based training within the School and through partnerships, enabling student dental nurses, dental hygienists and therapists to engage in outreach working opportunities where primary care is delivered.

Its programmes were developed in partnership with the Hampshire and Isle of Wight NHS Workforce Development Confederation and Primary Care Trusts. Awards offered include a BSc in Dental Hygiene and Dental Therapy, a Certificate of Higher Education in Dental Nursing and a Foundation Award in Science and Dental Therapy.

For further information on these courses at the University of Portsmouth contact Carol Gough on 02392843946.

en in different environments including general dental practice while theoretical training can be obtained in different ways including attending a formal course and/or accessing the BDA's online lecture course which is currently in development.

On completion of both the practical and theory elements of the training, dental nurses will be entitled to sit the exam which is organised by the NEBDN and will be held twice a year. For further information please visit www.nebdn.org or contact Mrs Jennifer Lavery on: 01253778417.

Also have a look at the dental radiography article, 'Excellent $X$-rays' on page 45.
'Talking Teeth' for National Smile Week

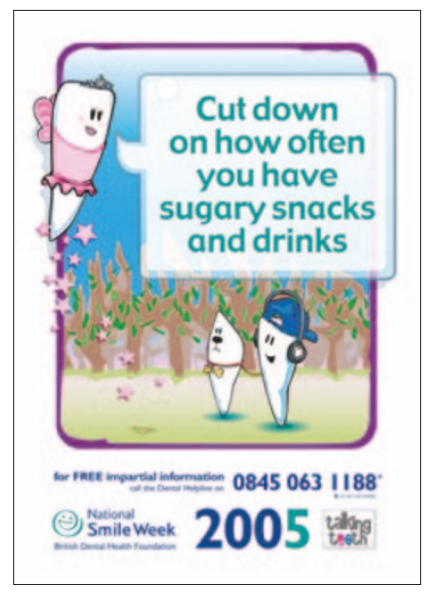

The British Dental Health Foundation has announced the theme and dates for this year's National Smile Week, and is urging all members of the dental team to get involved by organising an event.

National Smile Week is the UK's biggest annual oral health campaign. Now in its 29th year, this year's event will run from Sunday, May 15 to Saturday, May 21.

This year's focus will be on 'Talking Teeth' and the campaign will centre on the theme of Friends and Communication - encouraging the profession and the public to pass on oral health messages to those around them.

The aim of National Smile Week is to provide simple, practical oral health information to as many people as possible, and the Foundation hopes that the theme will encourage dental professionals around the country to get involved in passing this advice on to their patients.

For this years' campaign, the Foundation is providing a free six-page guide called The Event Organiser. The guide contains oral health information relevant to this year's campaign, tips on organising a successful event and possible event ideas. For your free copy please contact the Foundation on 08707704014 .

Event organisers will also receive a National Smile Week Resources Catalogue, which is full of useful products designed specifically for this year's event. For more information visit www.dentalhealth.org.uk 


\section{news in brief}

Regular updates to

\section{your door}

\section{BDA Conference 2005}

This year's British Dental Conference and Exhibition programme in Glasgow on 19-21 May is designed to encompass many of the issues significant to PCDs. The seminars, workshops and lectures are relevant to all members of the dental team, covering management and teamwork as well as clinical topics. These include extending the clinical role of PCDs, the future role of dental nurses and a conscious sedation demonstration to name but a few.

Also available is a special 'Team Booking' discount option and you can also book individual tickets for the three-day event for $£ 90$ or one-day tickets for $£ 40$. Most tickets include free entry to the Friday night party at the Corinthian Glasgow. If you've never attended the conference before and you want a taster you can get free entry to selected seminars by registering for an 'exhibition only' ticket. (Exhibition tickets are free before 12 May).

GlaxoSmithKline (GSK) Consumer Healthcare's 'Talking Points in Dentistry' programme will celebrate its 20th Anniversary at the conference. Delegates can register for the Glasgow event using the BDA conference booking form via the BDA website.

For more information or to book visit www.bda-events.org or call 08701666625 .
New dental nurse scheme launched
A new dental nurse cadet scheme has been launched in Oldham that will see 17 new trainees heading for Oldham's dental surgeries. The scheme, the first of its kind, is modelled on the nurse cadet scheme and could ease the burden on NHS dentists.

The cadets have already been through 12 weeks at The Oldham College, and will now go into surgeries for four days each week to learn their trade by a dentist's side. They will eventually obtain NVQ levels 2 and 3, and at the end of two years they will be fully qualified dental nurses.

The scheme was developed by Oldham's consultant in dental public health Colette Bridgman with Donna Hough from the Workforce Confederation and Tony Spencer from The Oldham College and is part of a national push to bring more dentists to the NHS and to enable dental teams to deliver aspects of dentistry traditionally carried out by dentists.

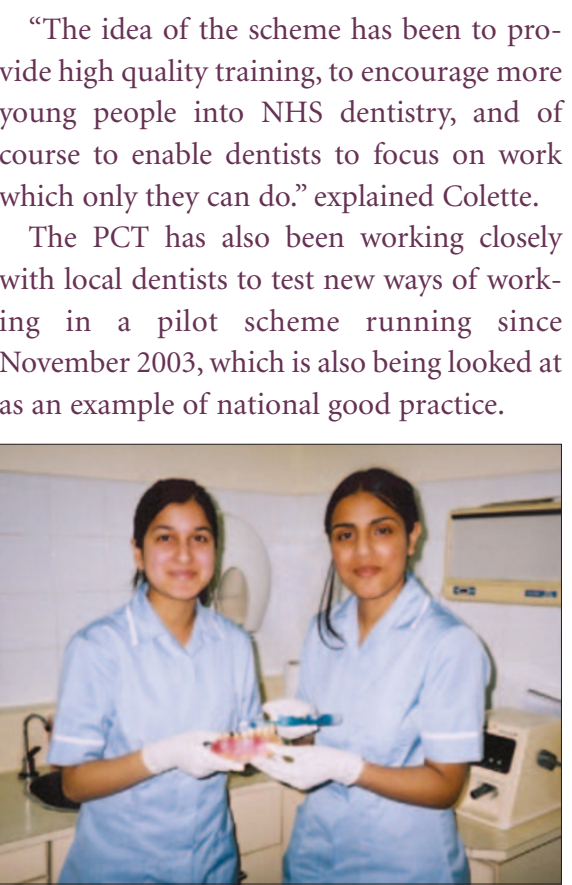

Safia Hussain and Rizwana Bogum Dental nurse cadets

\section{Association contacts}

\begin{tabular}{|c|c|c|}
\hline BRITISH ASSOCIATION OF & BRITISH DENTAL PRACTICE & DENTAL LABORATORIES \\
\hline DENTAL NURSES & MANAGERS' ASSOCIATION & ASSOCIATION \\
\hline Pam Swain (Chief Executive), & Bridget Crump (Chairman), & Michael Egerton (Chairman), \\
\hline PO Box 4, Room 200, Hillhouse & Osprey House, Primett Road, & 44-46 Wollaton Road, Beeston, \\
\hline International Business Centre, & Stevenage, Herts SG1 3EE & Nottingham NG9 2NR \\
\hline Thornton-Cleveleys FY5 4QD & 08708400381 & 08709914525 \\
\hline Tel.: $\quad 01253338360$ & E-mail: info@bdpma.org.uk & E-mail: enquiries@dla.org.uk \\
\hline $\begin{array}{ll}\text { E-mail: } & \text { admin@badn.org.uk } \\
\text { Website: } & \text { www.badn.org.uk }\end{array}$ & Website: www.bdpma.org.uk & Website: www.dla.org.uk \\
\hline & DENTAL TECHNICIANS' & ORTHODONTIC TECHNICIANS' \\
\hline BRITISH ASSOCIATION OF & ASSOCIATION & ASSOCIATION \\
\hline DENTAL THERAPISTS & Sue Adams (Registrar), & Paul Mallett (Secretary), \\
\hline Jane Lewis (Secretary), & PO Box 6520 & The Maxillofacial Laboratory, \\
\hline c/o 92 Mayfield Drive, Caversham, & Northampton NN3 9ZX & Royal Lancaster Infirmary, \\
\hline Reading, Berkshire RG4 5JT & 08702430753 & Ashton Road, Lancaster, \\
\hline 01189482651 & sueadams@dta-uk.org & Lancs LA1 4RP \\
\hline $\begin{array}{ll}\text { E-mail: } & \text { badt@freeuk.com } \\
\text { Website: } & \text { www.badt.org.uk }\end{array}$ & Website: http://www.dta-uk.org & Website: www.orthota.co.uk \\
\hline & ORTHODONTIC NATIONAL & BRITISH DENTAL RECEPTIONISTS' \\
\hline BRITISH DENTAL HYGIENISTS' & GROUP OF DENTAL NURSES & ASSOCIATION \\
\hline ASSOCIATION & Helen Grice-Roberts (Chairman), & Sue Surbey (Secretary), \\
\hline $\begin{array}{l}\text { Ann Craddock (Administrator), } \\
\text { Mobbs Miller House, Ardington Rd, }\end{array}$ & $\begin{array}{l}9 \text { Barge Close, Aldershot, } \\
\text { Hants GU11 2PB }\end{array}$ & $\begin{array}{l}23 \text { Newark Road, South Croydon, } \\
\text { Surrey CR2 6HR }\end{array}$ \\
\hline Northampton NN1 5LP & 01252341990 & 08700801924 \\
\hline 08702430752 & E-mail: Debra.claire@ & E-mail: sue@bdra.co.uk \\
\hline enquiries@bdha.org.uk & btinternet.com & Website: www.bdra.co.uk \\
\hline Website: www.bdha.org.uk & $\begin{array}{ll}\text { Website: } & \text { www.orthodontic } \\
& \text {-ong.co.uk }\end{array}$ & \\
\hline
\end{tabular}

